"maternalist" to describe the state seems to exaggerate the extent of this shift. Moreover, her conclusion that the welfare state that emerged at the end of this period "eradicated the ideology of separate spheres according to which female and male functions were complementary” (p. 312) seems entirely unsupported.

Despite my disagreements with Christie in the interpretation of some of her material, the strength and breadth of the material presented ensures that this book makes a valuable contribution to our knowledge on the rise of the welfare state, gender, family, and work.

Tracey L. Adams

University of Western Ontario

\title{
B. J. Rennie. The Rise of Agrarian Democracy: The United Farmers and Farm Women of Alberta, 1909-1921. Toronto: University of Toronto Press, 2000. Pp. 282.
}

The Rise of Agrarian Democracy is the story of how Alberta farmers built a movement that elected the longest lived experiment in farm populist government in North America-the United Farmers of Alberta (UFA) from 1921 to 1935.

B.J. Rennie's aim is to tell and analyze how this mass mobilisation arose through the development of "a movement culture" in three steps: first, the formation of a movement between 1879 and 1909; second, its initial steps as the UFA between 1909 and 1913 and then its deepening and expansion as a result of World War One; and third, a turn to political action with a decision to enter politics in 1919 in the provincial and federal elections of 1921.

To explain this evolution, the author uses the movement culture methods of Marxist labour historians like Bryan Palmer. In the case of Alberta farmers this leads Rennie to examine a dozen elements, such as gender, religion, co-operation, education, the agrarian myth, and social ethics. The author 
argues that the combination of these elements in the context of a frontier region, war, and insufficiently responsive governments gave rise to a populist class consciousness sufficiently united to take provincial power.

Such an approach considerably broadens the historical contexts of UFA mobilization by moving beyond the presidency of H.W. Wood and the annual convention to include the stories of United Farm Women and Youth. It notes how pervasive cooperative enterprise was and highlights the role of popular education methods from use of a newspaper, the Grain Growers' Guide, monthly meetings, annual events like the UFA convention and UFA Sunday, to the use of government production and extension of “debate packages” for independent farm purposes. And Rennie explains who and what a number of other leading farm men and women did in building a mass movement that peaked at over 35,000 members in 1921.

Rennie's movement culture method leads to a series of arguments challenging the regional/staple model of farm progressivism by historians such as W.L. Morton and political scientists like V.C. Fowke. To Rennie, class, not region, is the basis for farm mobilization as revealed in farmers' solutions such as the single land tax and direct legislation, measures Alberta pioneered. And, as census material reveals, mixed farming, not wheat, was the economic context driving Alberta farm concerns in the pre-1921 period. Livestock shipping, in fact, was the single largest business of the Alberta Farmers' Cooperative Elevator Company.

Rennie also documents the Alberta farm movement as a movement divided between liberals or market conservatives and radicals. Liberals like Wood promoted economic and political reform through lobbying the provincial Liberal government. Radicals, from the Society of Equity to the Non Partisan League (NPL), preached a transformation of economy and state through co-operation and direct democracy. These divisions were overcome in 1909 when the United Farmers was founded, and again in 1919 with a fusion of the NPL and the UFA to pursue political action. 
Identification of Wood as a liberal does much to clarify the conservative political nature of the radical-sounding doctrine of "group government" that Wood enunciated in 1919 as the basis for a fusion of radicals and liberals. Wood used "occupational representation," or local autonomy, as the defining principle of group government as a means to block co-operation between farm progressives and labour radicals, as in preventing affiliation of the UFA to the Cooperative Union of Canada. It was used to define political mobilization as a purely local affair with thresholds of 10 and 20 per cent of locals defining whether federal or provincial candidates be run. And Wood used it to prevent T.A. Crerar from using the national Canadian Council of Agriculture as a co-ordinated political mobilizer for the 1921 federal election. No "opening out" to a new Farm party or a coalition with radical labourites or socialists would be allowed if farmers were determined to enter politics. Farmers would remain lobbyists.

This definition of Wood as a market conservative who deflected radical progressivism behind the fiery rhetoric of group government explains a great deal as well about NPL leaders like William Irvine who initially opposed Wood's group government idea. Indeed the NPL fought a year-long battle (from 1919-20 with Wood inside the new UFA) over how farm politics were to be conducted. The NPL lost this battle and Irvine adapted to group government doctrines as expressed in his book, The Farmers in Politics (1921). Irvine hoped this narrow occupational politics could still lead to socialism.

Rennie's examination of the many popular dimensions, motives, and solutions to farm problems is a substantial advance in our understanding of the mass character and dynamics of UFA mobilization. However, the very strength, depth, and suppleness of Rennie's use of a movement culture method raises some questions when the method appears not to work.

Rennie's narrative and explanation of the politicization of the movement is not convincing. The chronological narrative gives a convoluted explanation of the 1919 decision to enter politics, then Liberal government attacks, before returning to the formal UFA leadership and organizational process of political 
mobilization. Rennie also goes to considerable lengths to assert how fundamentally democratic, as measured by rank-and-file control, the UFA remained as it politicized, when his own research consistently contradicts this by Wood's leadership behaviour. As well, Rennie provides repeated examples of political deflection, of the lobby for Direct Legislation as a substitute for independent politics before the war and the overwhelming pull to vote for the Union government in 1917, which briefly promised draft exemptions to farmers' sons.

This awkward bridge between the vibrant democracy of the mass mobilization of the UFA and its actual political translation is not a mistake. The objective dimensions of the movement, the property forms of production, the farm production systems, a charting of co-operative operations, and actual voting behaviour are absent. Such absences, including an explanation of the dynamics between radicals and liberals, between a class consciousness for itself versus a deflected class consciousness back into market liberalism, appear to be the product of a method that discounts the base of productive forces and relations and exalts the superstructure of cultural behaviours.

Rennie's study of UFA mobilization is a considerable achievement. But the "movement culture" method limits his account when class power, both in economics (ie: co-operation) and politics, has to be addressed.

Robin Wylie

Douglas College, Vancouver

Thérèse Hamel, Michel Morisset, Jacques Tondreau. De la terre à l'école. Histoire de l'enseignement agricole au Québec, 1926-1969. Montréal: Cahiers du Québec-Hurtubise HMH, 2000. 366 p.

C'est avec grand intérêt que nous avons ouvert cet ouvrage, car les travaux d'histoire de l'éducation consacrés à 